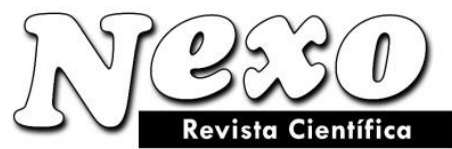

\title{
Renovation readiness matrix for cities
}

\section{Matriz de preparación de la renovación para ciudades}

\author{
Leonid Kievskiy ${ }^{1, *}$, Ilya Kievskiy ${ }^{1}$, Anastasia Sergeeva ${ }^{2}$ \\ ${ }^{1}$ LLC Scientific and Research Center "Development of a City", Moscow, Russian Federation \\ ${ }^{2}$ Russian Presidential Academy of National Economy and Public Administration, Moscow, Russian \\ Federation \\ *Corresponding author: leonid.kievskiy@mail.ru
}

(recibido/received: 17-mayo-2021; aceptado/accepted: 17-julio-2021)

\begin{abstract}
The accumulated positive experience of the housing stock renovation in Moscow puts issues of its distribution in other cities on a current agenda in many regions. The housing stock renovation program has an integrated impact on the social and economic development of the urban environment. However, economic factors are primarily important to the program implementation. The authors of this article have identified a number of economic criteria / parameters that help to assess the readiness for renovation in a particular city. The article introduces a Renovation Readiness Matrix that allows consolidating these parameters.
\end{abstract}

Keywords: Housing stock renovation program; Economic readiness for renovation.

\section{RESUMEN}

La experiencia positiva acumulada de la renovación del parque de viviendas en Moscú pone los problemas de su distribución en otras ciudades en una agenda actual en muchas regiones. El programa de renovación del parque de viviendas tiene un impacto integral en el desarrollo social y económico del entorno urbano. Sin embargo, los factores económicos son principalmente importantes para la implementación del programa. Los autores de este artículo han identificado una serie de criterios / parámetros económicos que ayudan a evaluar la preparación para la renovación en una ciudad en particular. El artículo presenta una Matriz de preparación para la renovación que permite consolidar estos parámetros.

Palabras claves: Programa de renovación del parque de viviendas; Disponibilidad económica para la renovación.

\section{INTRODUCTION}

The program of the housing stock renovation has an integrated impact on the social and economic development of the urban environment (Kievskiy et al., 2015). Foremost it is economic factors that determine the success of the program. If these factors are neglected, the renovation program becomes a social project to which the requirements and obligations of the current renovation program in Moscow cannot be applied. Thus, for renovation, as for any project evaluated from an economic point of view, economic feasibility is important. One of the main goals of such programs is profit generation. In other 
words, a renovation project needs to earn more than it is necessary to spend for its implementation (Kievskiy and Sergeeva, 2017a).

To start with, the authors concentrate on the parameters that allow us to assess the possibility of renovation in a particular city. The following calculated indicators take into account financial capabilities of the population, the need for housing renovation and the features of the real estate market:

- $\quad$ specific profitability of sales $(\boldsymbol{\omega})$,

- ratio of the average price of 1 sq. meters (the total area) in the primary housing market to the average monthly net wages $(\gamma)$.

The parameter of specific profitability of sales $(\boldsymbol{\omega})$, is the ratio of the difference between the selling price of one square meter of housing ( $\mathbf{I}_{\text {selling}}$ ) and construction cost of 1 sq. $\mathrm{m}$. of housing for sale $\left(\mathbf{C}_{\text {sale }}\right)$ to construction cost of 1 sq. $\mathrm{m}$. of housing for relocation $\left(\mathbf{C}_{\text {resettlement }}\right)$ times a coefficient of resettlement ( $\mathbf{K}_{\text {resettlement }}$ ) that is the ratio of the areas of provided and demolished housing (Kievskiy, 2018), see formula 1.

$$
\omega=\frac{I_{\text {selling }}-C_{\text {sale }}}{K_{\text {resettlement }} * C_{\text {resettlement }}}
$$

The higher specific profitability of sales $(\omega)$, the less housing volume needs to be sold to provide the necessary space for resettlement and demolition.

The ratio of the average price of 1 sq. meters (the total area) in the primary housing market to the average monthly net wages $(\gamma)$ is an indicator of housing affordability: the lower the value of the indicator, the more affordable housing is.

\section{METHODS}

Further, the authors compose a matrix that allows categorizing a particular city depending on the degree of its readiness for the renovation program. As an illustrative example, the authors use data for cities in Russia (Figure 1).

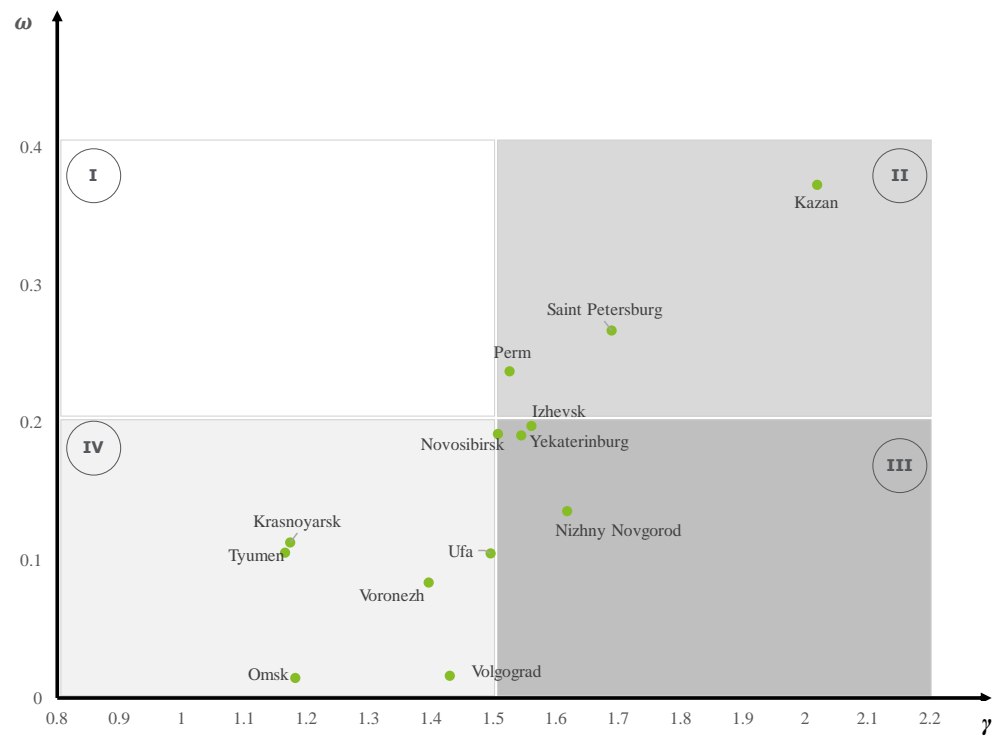


Figure 1. Renovation readiness matrix on the example of Russian cities (note: the values on the abscissa and ordinate axes are determined by a specific data sample; the division of the quadrants is based on the mean values for the data sample on both axes)

Further, the authors characterize the quadrants of the matrix. Upper left quadrant (I) includes cities with the strongest positions in both parameters at the same time: maximum sales profitability combined with maximum housing affordability. In this sample, none of the cities falls into this quadrant.

Upper right quadrant (II) contains cities with high sales profitability and relatively less affordable housing.

Lower right quadrant (III) includes cities with low profitability of sales and at the same time low-affordable housing.

Lower left quadrant (IV) comprises cities with low profitability of sales and relatively affordable housing.

Further the authors focus on additional parameters characterizing the readiness for renovation:

- Sales limit (L);

- Proportion of buildings (by area) that are potential participants in the renovation program to the housing stock in the city $(\mathbf{Z})$.

Sales limit $(\mathbf{L})$ reflects an ability of the real estate market in a particular city to the volume of premises built within the renovation program intended for sale. This parameter sets a kind of an upper bar for the possible sales volume (Kievskiy and Pljaskina, 2017; Kievskiy and Sergeeva, 2017b). The authors emphasize that forecasting the dynamics of the housing market with an increasing supply is a complex sophisticated task. That is why in the article there is a following assumption. The sales growth can be considered equivalent to an increase in the number of mortgage lenders taken by citizens, which can double (as maximum) compared to the current level, i.e. calculated for a year. However, taking into account an active growth of mortgages, the authors accept for the calculation a conservative correction factor to the amount of loans of 1.5 for volume of absorption in the housing market.

Proportion of buildings (by area) that are potential participants in the renovation program to the housing stock in the city $(\mathbf{Z})$ shows the volume of housing stock that meets the established characteristics in relation to the houses included in the program determined by the city authorities. For example, to assess the proportion of such buildings in the regions of Russia, the CIAN Analytical Center in its research ("Rating of the largest regional markets by the share of buildings - potential participants of the renovation program" https://spb.cian.ru/stati-kazhdyj-pjatyj-dom-v-regionah-mozhet-popast-pod-renovatsiju-302351/) considered four-, five- and six-story panel, block houses, built in 1955 - 1975, as well as some brick houses with similar characteristics (where the average floor area of an apartment does not exceed $50 \mathrm{sq} . \mathrm{m}$ ). 
a)

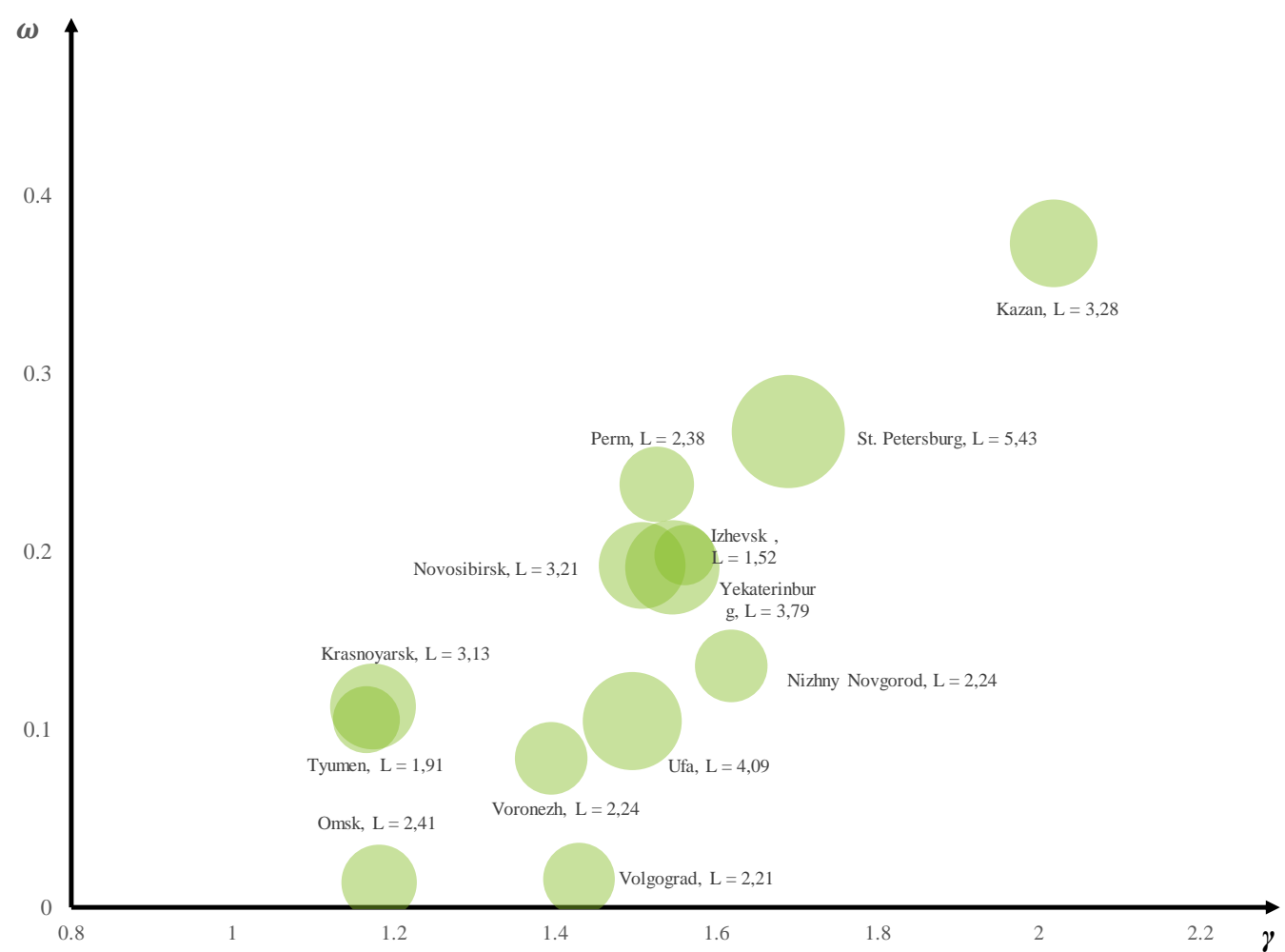

b)

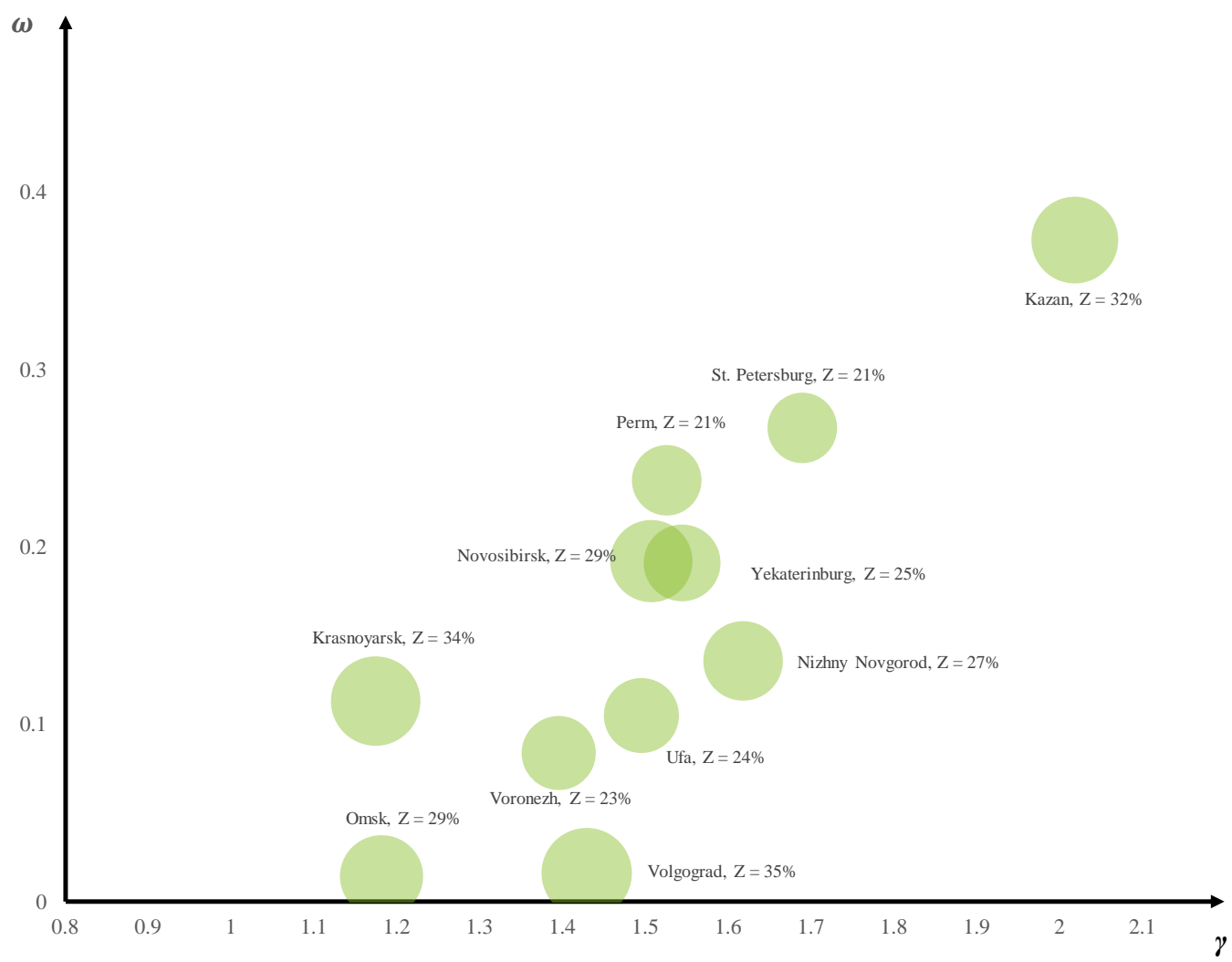

Figure 2. Comparative diagram of Russian cities by the parameters $\omega, \gamma, \mathbf{L}$ (a) and by the parameters $\omega, \gamma, \mathbf{Z}$ (b) 
Figure 2 clearly shows an upward trend. As the ratio of real estate prices to net wages $(\gamma)$ increases, the specific profitability of sales $(\boldsymbol{\omega})$, increases, and the corresponding cities have more opportunities to renovate existing housing stock. The data for the sample show that along with this, in most cases (Saint Petersburg, Kazan, Ufa, Yekaterinburg, Novosibirsk), the scale and volume of mortgage loans used is also growing. However, the values of the parameter $\mathbf{L}$ are distributed at random, since this calculated parameter depends not only on the volume of mortgage funds, but also on the areas acquired with a mortgage, taking into account market prices in a particular city.

The base data for the comparative diagrams (Figure 2) are summarized in Table 1, which is used to assess the renovation potential in cities.

Further, for an integral assessment of the overall potential of renovation in cities on the basis of the considered indicators $(\boldsymbol{\omega}, \boldsymbol{\gamma}, \mathbf{L}, \mathbf{Z})$, the authors use the following approach. The selected cities receives points for each indicator. The leading city receives 13 points (according to the number of cities in the sample), the city that took the last line - 1 point. In cases where there is no data, or the value of the parameter is negative, zero points are given. According to the indicator $(\gamma)$, a city with the most affordable housing, in which the ratio of the price of new buildings / average net wages of citizens, is the lowest, gets the maximum score. Further, the scores are summed up for all four indicators, i. e. the ranking of the city is calculated (Table 1).

Table 1. Assessment of the renovation potential in cities according to the main parameters

\begin{tabular}{|c|c|c|c|c|c|c|}
\hline & & $\begin{array}{l}\text { The ratio of the average } \\
\text { price of } 1 \text { sq. meters } \\
\text { (the total area) in the } \\
\text { primary housing } \\
\text { market to the average } \\
\text { monthly net wages }(\gamma) \text {, } \\
\text { units }\end{array}$ & $\begin{array}{c}\text { Specific } \\
\text { profitability of } \\
\text { sales }(\omega) \text { at } \\
K_{\text {resettlement, units }}\end{array}$ & $\begin{array}{l}\text { Sales limit (L), } \\
\text { thousand sq. m. }\end{array}$ & $\begin{array}{c}\text { Proportion of } \\
\text { buildings (by area) } \\
\text { that are potential } \\
\text { participants in the } \\
\text { renovation program } \\
\text { to the housing stock } \\
\text { in the city }(\mathrm{Z}), \%\end{array}$ & $\begin{array}{c}\text { Integrate } \\
\mathbf{d} \\
\text { ranking, } \\
\text { points }\end{array}$ \\
\hline 1 & 2 & 3 & 4 & 5 & 6 & 7 \\
\hline 1 & Krasnoyarsk & 1.17 & 0.11 & $3,134,377$ & $34 \%$ & 38 \\
\hline 2 & Kazan & 2.02 & 0.37 & $3,279,005$ & $32 \%$ & 35 \\
\hline 3 & Novosibirsk & 1.51 & 0.19 & $3,205,952$ & $29 \%$ & 35 \\
\hline 4 & Yekaterinburg & 1.55 & 0.19 & $3,787,660$ & $25 \%$ & 31 \\
\hline 5 & St. Petersburg & 1.69 & 0.27 & $5,425,775$ & $21 \%$ & 31 \\
\hline 6 & Ufa & 1.50 & 0.10 & $4,093,115$ & $24 \%$ & 30 \\
\hline 7 & Omsk & 1.18 & 0.01 & $2,412,328$ & $29 \%$ & 28 \\
\hline 8 & Volgograd & 1.43 & 0.02 & $2,210,503$ & $35 \%$ & 27 \\
\hline 9 & Perm & 1.53 & 0.24 & $2,384,161$ & $21 \%$ & 26 \\
\hline 10 & $\begin{array}{l}\text { Nizhny } \\
\text { Novgorod }\end{array}$ & 1.62 & 0.14 & $2,243,289$ & $27 \%$ & 23 \\
\hline 11 & Voronezh & 1.40 & 0.08 & $2,240,666$ & $23 \%$ & 22 \\
\hline 12 & Tyumen & 1.17 & 0.11 & $1,910,191$ & н/д & $20 *$ \\
\hline 13 & Izhevsk & 1.56 & 0.20 & $1,518,403$ & н/д & $15^{*}$ \\
\hline
\end{tabular}

Note. - * In case of absence of data for one or another parameter cities are conditionally included in the ranking calculation with a score of " 0 " for these parameters. 


\section{RESULTS AND DISCUSSION}

Thus, according to expert estimates, Krasnoyarsk, Kazan, Novosibirsk, Yekaterinburg and Saint Petersburg have relatively high economic readiness for renovation. The highest number of points was received by Krasnoyarsk, located in the IV quadrant of the Renovation readiness Matrix (cities with low rates of sales profitability and relatively affordable housing). Kazan and Saint Petersburg belong to the II quadrant (cities with high sales profitability and relatively less affordable housing), Novosibirsk and Yekaterinburg belong to the III quadrant (cities with low sales profitability and at the same time with low-affordable housing).

The largest for the sample positive delta resulting from a comparison of the market price of housing and the cost of construction is in Krasnoyarsk, Novosibirsk and Saint Petersburg indicates a possible economic feasibility of the renovation program in these cities. These cities have their own source of funds for renovation due to market conditions.

The indicative approach implemented in the analysis of this article allows to establish the main trends, but it does not take into account a number of factors, both contributing to effective renovation, and having a negative impact on it (Kievskiy et al., 2018; ). Among the factors that increase the possibility of renovation in a particular region or city are the following. Firstly, sales of commercial premises and parking lots in renovation quarters can be viewed as a part of a value comparison of potential. Secondly, influence of deferred demand in areas of existing housing stock also may be taken into account. Moreover, federal projects that are being implemented closely to renovated territories (road facilities, sports large-scale events) may matter as well (Lenkovets, 2020).

Among the possible negative there are the following factors: a need to allocate additional funds from the city budget during the starting period of the program that does not involve sales (as in Moscow); a need to invest in construction of social and cultural facilities, engineering and roads in the renovation quarters, etc. Such aspects may be important and should be taken into account during a renovation program (or its equivalent) development in each particular city.

\section{CONCLUSION}

The simplifications and assumptions made by the authors in the calculations are multidirectional. Some of them increase the estimated potential for renovation. For instance the authors use construction costs and housing absorption volume in the regions (and not in specific cities). At the same time, some other assumptions underestimate the possibility of renovation a little. For example the authors use the average monthly wage (rather than per capita income) and a low coefficient (1.5) to calculate housing absorption.

In conclusion, taken together, there is a fundamental possibility of renovation in large cities, and it is advisable to proceed to specific calculations for each city based on the described methodology and upon orders of local municipalities.

\section{REFERENCES}

Kievskiy, I. L., Kievskiy, L. V. and Argunov, S. V. (2018). Multiple effects of renovation. In: I.L. Kievskiy (Ed.), Renovaciya. Krupnomasshtabnyj gorodskoj proekt rassredotochennogo stroitel'stva: monografiya o nauchno-metodicheskih podhodah i nachale realizacii programmy [Renovation. Large-scale urban dispersed construction project: monograph on scientific and methodological approaches and the beginning of the program] (pp. 182-191). Moscow, Russia: Russkaya shkola Publ. [in Russian]. 
Kievskiy, I. L. and Pljaskina, A. T. (2017). Readiness of the market of building materials and machines in the Central Federal District of Russia to the program of renovation in Moscow. Industrial and Civil Engineering, 11, 88-93.

Kievskiy, L. V. (2018). The mathematical model of renovation. Zhilishhnoe stroitel'stvo, 1-2, 3-7 [in Russian].

Kievskiy, L. V., Kievskaya, R. L. and Mareev, U. A. (2015). Main methodic directions of forming the urban development rating. Housing Construction, 12, 3-8.

Kievskiy, L. V. and Sergeeva, A. A. (2017a). Evaluation of the effects of urban development measures on the renovation of the quarters of the existing buildings in Moscow and their impact on the need for construction machines. Naukovedenie Internet Journal, 9 (6), 1-17. https://naukovedenie.ru/PDF/108TVN617.pdf (accessed 20.12.2019) [in Russian].

Kievskiy, L. V. and Sergeeva, A. A. (2017b). Renovation planning and effective demand. Zhilishhnoe stroitel'stvo, 12, 3-7 [in Russian].

Lenkovets, O.M. Housing Renovation in Russia and Engineering and Environmental Aspects of Renovation Programs. Journal of Advanced Research in Dynamical and Control Systems, 12(4), 1060-1068. 